http:/ / dx.doi.org/10.5597/lajam00153

\title{
Report of the Working Group on Major Threats and Conservation
}

\author{
Enrique A. Crespo ${ }^{1, *}$, Daniela Alarcon ${ }^{2}$, Mariana Alonso ${ }^{3}$, Mariel Bazzalo $^{4}$, Monica Borobia $^{5}$, Marta \\ Cremer $^{6}$, Gislaine Filla ${ }^{7}$, Liliane Lodi ${ }^{8}$, Fagner A. Magalhães ${ }^{9}$, Juliana Marigo ${ }^{10}$, Helder Lima de Queiróz ${ }^{11}$, \\ John E. Reynolds, III ${ }^{12}$, Yara Schaeffer ${ }^{13}$, Paulo R. Dorneles ${ }^{14}$, José Lailson-Brito ${ }^{15}$ and Dana L. Wetzel ${ }^{12}$
}

\section{Introduction}

The species of the genus Sotalia inhabit river and lake systems of Amazonia, the lower Orinoco River, and coastal marine waters from Nicaragua to southern Brazil (Borobia et al., 1991; da Silva and Best, 1994; 1996; Carr and Bonde 2000; Flores and da Silva, 2009). Freshwater and marine animals can be differentiated based on skeletal morphology (Monteiro Filho et al., 2002). Recently they were demonstrated to be separate species, with $S$. fluviatilis being the riverine species in the Amazon and $S$. guianensis being found in marine and estuarine environments (Cunha et al., 2005; Caballero et al., 2007). The identity of the animals found in the Orinoco system remains unclear (see Solé-Cava et al. 2010, this volume). Both species are believed to be locally abundant, although numbers reported for some areas (such as Guanabara Bay, Rio de Janeiro) seem to have declined (Santos et al., 2010, this volume; Azevedo et al., 2008). Common names for the riverine species $S$. fluviatilis include 'tucuxi' in Brazil or 'bufeo negro' in other countries, while the marine species $S$. guianensis is called 'boto-cinza', or simply 'boto' or 'golfinho' in Brazil. The proposed English common name for S. guianensis is 'Guiana dolphin' (Flores et al., 2010 this volume).

The freshwater and near-shore marine distribution means that both Sotalia species are vulnerable to the effects of anthropogenic activities, including water development projects, chemical pollution, noise, as well as by-catch. The Scientific Committee of the International Whaling Commission (IWC) urged in 1994 that steps should be taken by member states to reduce incidental mortality of Sotalia, while at the same time establishing better systems of recording and monitoring take levels (IWC, 1995).
A particular concern has been expressed for the status of mangrove forests, which are threatened in many areas by pollution and coastal development. Several Guiana dolphin populations probably depend to a considerable extent on the productivity derived from mangrove ecosystems (Zanelatto, 2001) and may be particularly vulnerable as the species appears to occur in a series of small resident populations along the Brazilian coast (e.g. Geise and Borobia, 1988; Santos et al. 2001; Rossi-Santos et al., 2007; Nery et al., 2008a).

This report presents the discussions of the group tasked with covering Major Threats and Conservation at the 'Workshop on Research and Conservation of the genus Sotalia' held in Armação dos Búzios, Rio de Janeiro, Brazil, 19-23 June 2006. It is intended as a compilation of information supplied by workshop participants and from a literature review. This report is organized by type of threats: documented and potential. Participants also reviewed aspects of regulations and legislation in the different countries, which are included in this report.

\section{Documented Threats}

\section{FISHERIES INTERACTIONS}

Mortality in fishing gear is likely the most important threat to the conservation of small cetaceans worldwide (Reeves et al., 2003). Fishermen and dolphins often interact, in many different ways, throughout Amazonia and Orinoquia, as well as along the coastal zone of Central and South America. Interactions include incidental mortality in different types of nets, the use of dynamite in fishing operations, direct catches for meat consumption and bait, and competition with fisheries

\footnotetext{
${ }^{1}$ Centro Nacional Patagónico (CONICET), Universidad Nacional de la Patagonia \& IUCN Cetacean Specialist Group, 9120 Puerto Madryn, Chubut, Argentina

${ }^{2}$ Universidade Estadual de Santa Cruz, Ilhéus, Bahia, Brazil

${ }^{3}$ Laboratório de Química Orgânica Marinha, Instituto Oceanográfico da Universidade de São Paulo.

${ }^{4}$ Doctorado en Cs. Biológicas, FCEyN-UBA, Argentina

${ }^{5}$ Roteiros de Charme, Rio de Janeiro, Brazil

${ }^{6}$ Universidade da Região de Joinville, Departamento de Ciências Biológicas, Laboratório de Nectologia.

${ }^{7}$ Instituto de Pesquisas de Cananéia, Cananéia, São Paulo, Brazil

${ }^{8}$ Instituto de Estudos da Ecologia de Mamíferos Marinhos, Niterói, Rio de Janeiro, Brazil

${ }^{9}$ Projeto Cetáceos do Maranhão, Ilha do Caju Institute, Parnaíba/PI, Brazil

${ }^{10}$ Projeto BioPesca, SP, Departamentos de Biologia e Genética, IOC-FIOCRUZ, Brazil

${ }^{11}$ Instituto Mamirauá, Tefé, Amazonas, Brazil

${ }^{12}$ Mote Marine Laboratory, Sarasota, Florida, USA

${ }^{13}$ BIOMA, Oceanographic Institute, University of São Paulo, Brazil

${ }^{14}$ Instituto de Biofísica Carlos Chagas Filho, Universidade Federal do Rio de Janeiro, Brazil

${ }^{15}$ Laboratório de Mamíferos Aquáticos e Bioindicadores 'Profa. Izabel Gurgel', Faculdade de Oceanografia, Universidade do Estado do Rio de Janeiro, Brazil

* Corresponding author, e-mail: kike@cenpat.edu.ar, kike.crespo@uv.es
} 
for fishing resources (Lodi and Capistrano, 1990; Di Beneditto et al., 1998; Monteiro Neto et al., 2000; Nery et al., 2008b; Pinheiro and Cremer, 2004; Loch et al., 2009).

In the central Amazon of Brazil, tucuxis interact with several types of fisheries, such as those using set or floating gillnets and 'lampara' seines (Best and da Silva, 1989). Artisanal fishermen with traditional gear such as hooks, arrows, and 'tarrafas' (throw-nets) look for dolphins in order to detect concentrations of fish (Barthem and Goulding, 1997). For the most part, they do not perceive dolphins as competitors or enemies. In contrast, fishermen who set driftnets in the main channels of the rivers to catch large silurids (catfish) regard dolphins as pests. They sometimes shoot them with guns or throw poisoned fish at them. Even though the fishermen recognize that other fishes (e.g. family Cetopsidae, whale catfishes) may steal or mutilate their catch and cause losses to the fisheries, they often use the dolphins as scapegoats.

Tucuxis are generally not hunted, but they appear to be extremely vulnerable to entanglement in gillnets. A study of by-catch in the mouth of the Amazon based on interviews with fishermen indicated a kill of more than 1050 tucuxis in a single year (Beltrán, 1998). Loch et al. (2009) reported two carcasses of S. fluviatilis found dead with signs of perforations and cuts in the western Brazilian Amazon. In Colombia, river dolphins are killed in order to sell their body parts (including eyes, teeth, genital organs and oil), which are used as aphrodisiacs and amulets in local markets in Leticia (Amazonas) and Puerto Carreño (Vichada) (Trujillo, 1990). It was mentioned that in some cases an eye can be sold by $\$ 10$ USD (F.A. Magalhaes, pers. obs.). It is of concern that a market could be developed and that an incidental catch could turn into a directed one (Alves and Rosas, 2008).

In the coastal zone, several types of fishing gear are involved in incidental captures of dolphins, such as gillnets, driftnets, beach seines, trawling nets, long-lines and fixed traps (Siciliano, 1994). However, more than $90 \%$ of catches have been reported in gillnets. Many records exist of strandings along the species range. An unknown proportion may be caused by incidental captures, suggesting potentially high levels of by-catch. When dolphins are caught incidentally, sometimes they are killed with knives in order to remove eyes and genital organs. However, the most common use of incidentally caught specimens in the coastal zone is to take advantage of blubber as bait for long-lines (Siciliano, 1994). Guiana dolphins along with franciscanas (Pontoporia blainvillei) are the most commonly caught small cetaceans in Brazilian coastal gillnet fisheries (Siciliano, 1994; Monteiro Neto et al., 2000; Di Beneditto, 2003). The Guiana dolphin may also be the cetacean most commonly taken as a by-catch in coastal fisheries of the southern Caribbean Sea (Vidal et al., 1994).

Recent work has been carried out on Guiana dolphins to mitigate fisheries interactions, including experimentation with pingers. From 1996 to 1998, a series of trials were carried out in Iracema Beach, Fortaleza, Brazil by Monteiro Neto et al. (2004). Experiments with functional, dummy and control trials were tested in a sheltered area where dolphin groups were monitored. Significant differences in the distribution of dolphins were observed between areas with functional pingers compared to areas with dummy ones or control trials, where no pingers were set. The average sighting frequency was lower than that observed in areas with active pingers. These results suggested that functional pingers affect dolphin distribution.

\section{POLLUTION}

Persistent Bioaccumulative Toxicant (PBT) concentrations are generally found in marine mammal species that inhabit coastal or fluvial waters of the highly industrialized and/or populated countries. Due to heterogeneity in the distribution of people and industries in Latin America, as well as to peculiarities of land use, there are hotspots of chemical pollution along the distribution of Sotalia species. This is especially the case for the coastal environments in Brazil.

Trace element concentrations reported for Guiana dolphins were found to be within the expected range for coastal cetaceans (Lailson-Brito, 1994; 2000; Monteiro Neto et al., 2003) and, in some situations, they were even lower than the levels verified in cetaceans inhabiting other less disturbed regions (Lailson-Brito and Fernandez, 199716; Lailson-Brito et al., 2000). This has been the case for cadmium, that does not seem to constitute a toxicological problem for Guiana dolphins (Lailson-Brito et al., 2000; Kunito et al., 2004; Dorneles et al., 2007; Seixas et al., 2009a; 2009b); however, other heavy metals such as tin and mercury show higher concentrations.

A recent investigation comprised the evaluation of cetacean exposure to organotin compounds (OTs) through hepatic total tin (TSn) concentrations in Guanabara Bay (Rio de Janeiro State, Brazil), the most degraded area along the distribution of S. guianensis (Lailson-Brito, 2007). The study demonstrated extremely high levels of TSn, and comparatively higher than those measured in Guiana dolphins from Espírito Santo State $\left(\sim 20^{\circ} \mathrm{S}\right)$ or in other delphinid species that inhabit continental shelf and oceanic waters off Rio de Janeiro State (Dorneles et al., 2008a).

Total mercury $(\mathrm{THg})$ and methylmercury $(\mathrm{MeHg})$ have been found in high concentrations in muscle and liver

\footnotetext{
${ }^{16}$ Lailson-Brito JR., J. And Fernandez, M.A. (1997) Concentrações de metais pesados em tecidos do golfinho-de-clymene, Stenella clymene, e do boto-cinza, Sotalia fluviatilis, da costa nordeste do brasil. In XI Encontro de Zoologia do Nordeste, Fortaleza, 1997.
} 
samples of Guiana dolphins from Guanabara Bay; however, they probably do not have toxicological consequences for the dolphins (Lailson-Brito et al., 2002; Lailson-Brito, 2007).

With reference to organochlorine compounds (OC), most of the studies addressing Sotalia have focused on dichlorodiphenyltrichloroethane and its metabolites ( $\mathrm{DDT})$, as well as on polychlorinated biphenyls (PCBs). High $\Sigma D D T$ and LPCB concentrations were found in blubber samples from Guiana dolphins from Guanabara Bay (Lailson-Brito et al., 2003; Torres et al., 2006; Lailson-Brito et al., 2010) and southern São Paulo and northern Paraná States (Yogui et al., 2003; 2010; Kajiwara et al., 2004). The organochlorine levels observed in these studies are comparable to those found in cetaceans from highly industrialized regions of the Northern Hemisphere, and higher than OC concentrations found for the same species in other coastal bays (Sepetiba, Ilha Grande and Paranaguá bays) in Brazil (Lailson-Brito et al., 2010; Vidal, 2010). Concentrations of the most toxic OCs, i.e. polychlorinated-dibenzo-p-dioxins (PCDDs), dibenzofurans (PCDFs) and some polychlorinatedbiphenyls (PCBs) called dioxin-like PCBs (dl-PCBs), have also been detected in blubber samples from Guiana dolphins from Guanabara Bay (Dorneles et al., 2008b) .

Only a few investigations based on a small sample size have been carried out outside Brazil. Koeman et al. (1972) reported micropollutant concentrations in a Guiana dolphin collected in Suriname. Duinker et al. (1989) analyzed micropollutant ( $\Sigma \mathrm{DDT}$ and $\Sigma \mathrm{PCB}$ ) concentrations from a male and a female Guiana dolphin from Colombia and found them to be similar to the lower range of concentrations found in south and southeast Brazil and Suriname.

Regarding organohalogen compounds other than organochlorines, high concentrations of perfluorooctane sulfonate (PFOS) have been found in hepatic samples of Guiana dolphins from Guanabara Bay, even among the highest ever reported for cetaceans (Dorneles et al., 2008c). Similar values of Polybrominated diphenyl ethers (PBDEs) in Guiana dolphins from Guanabara Bay have been found with those reported by Covaci et al. (2002) in North Sea harbor porpoises (Phocoena phocoena) (Dorneles et al., 2010).

Regarding tucuxi dolphins, due to the history of chemical contamination in the Amazon basin, $\mathrm{Hg}$ and
DDT are the micropollutants that raise the highest environmental concern. It is interesting, however, that none of the liver samples from 22 Guanabara Bay dolphins analyzed by Lailson-Brito (2007) rendered an hepatic $\mathrm{Hg}$ concentration higher than the one found in a tucuxi from Negro River, in the Amazon, where less mining has occurred (Lailson et al., 2008).

\section{NOISE POLLUTION}

The influence of background noise created by human activities is poorly studied. Despite the lack of sound pollution assessments, noise produced by boat engines seems to affect the whistle production and acoustic structure of Guiana dolphin whistles (Dias, 2007). Surface behavioral responses of Guiana dolphins to boats have been reported for southern Brazil, where dolphins usually avoid different types of boats regardless the type of approach (Pereira et al., 2007). Other sources of noise, such as those from dredges and pile-drivers, as well as other heavy machines used for harbor enlargement, have been argued to be the cause for the abandonment of the harbor inlet by the dolphins in Babitonga Bay, Brazil (Cremer et al., 2009). Diazgranados et al. (2002) ${ }^{17}$ recorded changes in the acoustic signals, respiratory patterns and behavior of tucuxi and botos in the Colombian Amazon before, during and after exposure to outboard propellers from boats crossing the river in high speed.

\section{EMERGING DISEASES}

Several diseases have been documented in Sotalia dolphins such as viral genital papillomatosis from Brazil (M. Marcondes, pers. comm.), generalized poxvirus infection in a Guiana dolphin calf from Brazil (S. Siciliano, pers. comm.), toxoplasmosis in a Guiana dolphin from Brazil (Bandoli and de Oliveira 1977) and lobomycosis and lobomycosis-like disease in Guiana dolphins from several localities (Caldwell et al. 1975, Symmers 1983, Paniz-Mondolfi et al. 2007, Van Bressem et al. 2007; 2009).

\section{Potential threats}

\section{OTHER CONTAMINANTS}

Regarding chemical pollution, it is likely that Guiana dolphins inhabit several hotspots of environmental contamination by polycyclic aromatic hydrocarbons (PAHs). Oil spills have been mentioned as a potential threat in Peru (McGuire, 2006 ${ }^{18}$ ). The use of biomarkers

\footnotetext{
${ }^{17}$ Diazgranados, M.C., Mejía, P. And Acosta, A. (2002) Effect of boat traffic on the vocal and surfacing behavior of river dolphins: A key for abundance estimation methods (Abstract 5pAB3). Page 2431 in Proceedings, First Pan-American/Iberian Meeting on Acoustics, December 2002, Cancún, Mexico. Journal of the Acoustical Society of America 112(5)(Pt. 2).

${ }^{18}$ McGuire, T.L. (2006) Ecology and conservation status of riverine tucuxi (Sotalia fluviatilis) in the Pacaya-Samiria Reserve, Peru. Page 17 in Siciliano, S., Borobia, M., Barros, N.B., Marques, F., Trujillo, F. and Flores, P.A.C. (Eds), Book of Abstracts, Workshop on Research and Conservation of the genus Sotalia, 19-23 June 2006, Armação dos Búzios, Rio de Janeiro, Brazil. Latin American Journal of Aquatic Mammals 8(1-2) (supplement). http://dx.doi.org/10.5597/lajam00147.a007
} 
of exposure to and/or effects of pollutants might become a valuable tool (Aguilar, 1987).

Planned WATER DeVelopment in the Amazon and ORINOco BASINS

Dams and other types of barriers have been constructed in many of the world's rivers for hydroelectric power generation, flood control, and irrigation, producing population fragmentation and major changes in the physical and ecological attributes of the environment (Smith and Reeves, 2000; Smith et al., 2000). In the Amazon and Orinoco basins several large dams have already been built, and numerous others are planned or are being considered (Best and da Silva, 1989). Another consequence of the construction of dams is the increase in methylmercury synthesis by microorganisms, associated with anaerobic degradation of the flooded organic matter (Guimarães et al., 2000). It is likely that these barriers have affected (or will in the future) riverine species such as Sotalia.

\section{SHRIMP FARMING IN THE COASTAL ZONE}

The impacts of shrimp monoculture on coastal wetlands and mangroves are unambiguous. They involve extreme hydrologic and topographic transformation of the intertidal flat. The occupation of coastal habitats also takes place on a landscape-level scale. As coastal habitats such as estuaries, lagoons and mangroves are important to Sotalia (see da Silva et al., 2010, this volume), with shrimp farming occurring in various portions of its range. It was suggested at the Workshop that shorebirds have the potential to be used as indicators of regional coastal wetland functional integrity; however, marine mammal conservation must be seen as an integral part of coastal resource and biodiversity conservation to support sustainable fisheries.

\section{HabitAT LOSS IN COASTAL AREAS AND AMAZON BASIN}

Many Guiana dolphin populations are located near the most populated cities or close to strategic tourism destinations or large-scale aquaculture developments, which make them vulnerable to habitat degradation and loss associated to coastal ecosystems like beaches, mangroves and 'restingas'. A high number of construction works are planned for the establishment of harbors, shipyards and industries on coastal bays and estuaries along Brazil and it is likely that their fate will follow the same degradation path of Guanabara Bay. A documented case is the Bay of Santos, were in the beginning of the 20th Century Guiana dolphins used to be found (Luederwaldt, 1919). The largest port in South America was built in the area ca. 120 years ago (CODESP, 1992) and today no dolphins are found in this highly impacted estuary.
The distribution of tucuxi dolphins in Ecuador overlaps areas of intensive use by human populations (Utreras et al., 2000; Zapata-Ríos and Utreras 2004), where habitat degradation of river and lake systems is likely to be a principal threat to local tucuxi populations. Moreover, growing human populations, the intensification of oil industry activities and the expansion of large-scale agriculture in the Ecuadorian Amazon threaten with water pollution, an increase use of outboard motors, and fishing using nets and explosives, as well as with chemical agents.

\section{Conservation status}

LEGAL FRAMEWORK

Sotalia species have been included in the Convention on International Trade in Endangered Species of Wild Fauna and Flora (CITES) Appendix I since 1982 (ITIS, in Appendix II of CMS, and listed as 'Data Deficient' by IUCN). As threats can be different in each country, the IUCN has promoted Red Data Books of endangered species for each one. The category for Sotalia varies from 'Data Deficient' in Brazil (IBAMA, 2001), 'Vulnerable' in Colombia (Rodríguez-Mahecha et al., 2006) and Venezuela (Rodríguez and Rojas-Suárez, 2008) to 'Endangered' in Ecuador (Tirira, 2001). Despite these local categorizations, the IUCN adopted a different classification at the international level, and Sotalia species are considered 'Data Deficient' (Secchi, 2010) ${ }^{19}$. In Brazil, Peru, and Colombia national legislation protects cetaceans, including Sotalia dolphins (Culik, 2004). Sotalia dolphins are indirectly protected by various legal frameworks in Ecuador, Venezuela, Guyana and French Guiana (Table 1).

Small cetaceans are considered under the Convention on Migratory Species of Wild Animals (Culik, 2004), which is a multilateral legally binding agreement fostered under the auspices of the United Nations Environment Programme (CMS-UNEP). The Regional Seas Programme of UNEP has also promoted regional conservation of marine mammals through the adoption of Regional Marine Mammal Action Plans by member Governments. Two of them are relevant for Sotalia species: the Action Plan for the Conservation of Marine Mammals in the South-East Pacific and the Action Plan for the Conservation of Marine Mammals in the Wider Caribbean Region.

\section{PROTECTED AREAS}

A number of countries along the distribution of Sotalia species have established marine protected areas for the conservation of cetacean populations. To date, however, the only known protected area explicitly created with

${ }^{19}$ SeCCHI, E. (2010) Sotalia fluviatilis. In: IUCN 2010. IUCN Red List of Threatened Species. Version 2010.4. <http:// www.iucnredlist.org>. 
the aim of protecting a local Sotalia population is the 'Anhatomirim Area of Environmental Protection,' established by Law in 1992 (Decreto 528/1992). After 18 years of existence, however, no management plan, as required in the Brazilian National Legislation, has been adopted, nor have management actions been enforced in this area. The lack of such management measures indicates that the protected area is not fully functional and has yet to respond to the objectives for which it was established (Wedekin et al., 2005).

The Cayos Miskito Reserve, established in 1991 in Nicaragua, is located within one of the larger tracts of wilderness remaining in Central America (Edwards and Schnell, 2001) and the mangrove-lined lagoons and rivers that characterize the coastline of the Reserve form a continuous estuarine region and support significant numbers of Guiana dolphins (Carr and Bonde 2000). The Pacaya-Samiria Reserve, in the Peruvian Amazon, appeared to contain a significant number of tucuxis, as indicated by population estimates in the Samiria River system over the period 1991-2000 (Leatherwood, 1996; Henningsen, 1998; Zúñiga, 1999; McGuire, 2002; 2006 ${ }^{18}$ ).

\section{Recommendations from the Workshop}

\section{GENERAL RECOMMENDATIONS}

1) Develop a Geographic Information System (GIS) tool to map layers on (a) incidental catch, (b) direct catch, (c) chemical contamination of different types, (d) development activities associated with chemical contamination, (e.g. oil/gas; mining), (e) tourism and other human activities.

Table 1. National legislation applicable to the conservation of Sotalia dolphins.

\begin{tabular}{|c|c|}
\hline COUNTRY & LEGISLATION \\
\hline Honduras & No information available \\
\hline Nicaragua & Presidential Decree (1991) - Create Cayos Miskito Reserve \\
\hline Costa Rica & No information available \\
\hline Panama & No information available \\
\hline Colombia & $\begin{array}{l}\text { Law (2005) from the Ministry of Environment and Territorial Development of Colombia. } \\
\text { Sotalia guianensis was declared as vulnerable species under the criteria of the IUCN. } \\
\text { Prohibited the intentional capture and captivity of this species. Sotalia fluviatilis was declare } \\
\text { as endangered in Colombian territory. }\end{array}$ \\
\hline Venezuela & $\begin{array}{l}\text { Presidential Decree No. } 1485 \text { (1996). Species protected from hunting } \\
\text { Presidential Decree No. } 1486 \text { (1996). On endangered species }\end{array}$ \\
\hline \multirow[t]{3}{*}{ Brazil } & $\begin{array}{l}\text { Federal Laws } \\
\text { - } \quad \mathrm{N}^{\circ} 5197 \text { (03 Jan. 1967). Protection of Fauna. Modifications: } \mathrm{N}^{\circ} 7653 \text { (17 Feb. 1988) and } \mathrm{N}^{\mathrm{o}} \\
\quad 9111 \text { (10 Oct. 1995) } \\
\text { - } \quad \mathrm{N}^{\circ} 6938 \text { (31 Aug. 1981). National Environmental Policy, its objectives and } \\
\text { implementation mechanisms. } \\
\text { - } \quad \mathrm{N}^{\mathrm{o}} 7643 \text { (18 Dec. 1987). Prohibition of hunting or any form of intentional harassment of } \\
\text { cetaceans in national jurisdiction waters. } \\
\text { - } \quad \mathrm{N}^{\circ} 9605 \text { (12 Feb. 1998). Penal and administrative sanctions from detrimental behavior and } \\
\text { activities to the environment (a.k.a. Environmental Crimes Law). } \\
\text { - } \quad \mathrm{N}^{\circ} 9985 \text { (18 Jul. 2000) - National System of Protected Areas }\end{array}$ \\
\hline & $\begin{array}{l}\text { Federal Decrees } \\
\text { - } \quad \mathrm{N}^{\circ} 88218 \text { (06 Apr. 1983). Create the Abrolhos National Marine Park } \\
\text { - } \quad \mathrm{N}^{\circ} 528 \text { (20 May 1992). Create and define the limits of the Anhatomirim Environmental } \\
\quad \text { Protection Area, specially created to protect the local population of Sotalia fluviatilis. } \\
\text { - } \quad \mathrm{N}^{\circ} 3179 \text { (21 Oct. 1999). Regulations pertaining to the Environmental Crimes Law. }\end{array}$ \\
\hline & $\begin{array}{l}\text { Regulations } \\
\text { IBAMA(Instituto Brasileiro de Meio Ambiente e Recursos Naturais Renováveis). No } 117 \\
\text { (26 Dec. 1996. Regulations to prevent harassment in national jurisdictional waters. } \\
\text { IBAMA N } \mathrm{N}^{\circ} \text { 05-N (20 Jan. 1998. Establish regulations to safeguard the reproduction, } \\
\text { resting, and calving of Sotalia fluviatilis in the Anhatomirim Environmental Protection } \\
\text { Area, Santa Catarina. } \\
\text { IBAMA N } 98 \text { (14 Apr. 2000). Regulations for the maintenance and management of } \\
\text { aquatic mammals in captivity with the objectives of rehabilitation, research, education } \\
\text { and public display. }\end{array}$ \\
\hline Ecuador & $\begin{array}{l}\text { Resolution of Ministry of Environment No. 105, Register No. } 5 \text { ( } 28 \text { Jan. 2000). Prohibits } \\
\text { hunting of Sotalia fluviatilis. }\end{array}$ \\
\hline Peru & The Pacaya-Samiria Reserve \\
\hline
\end{tabular}


2) Further develop existing stranding networks and sampling programs in order to collect tissues of Sotalia as well as biopsies for integrated ecological studies.

\section{Specific recommendations}

\section{INCIDENTAL AND DIRECT CATCH}

1) Enhance and further develop systematic and standardized collection of data on mortality, fishing efforts, detailed description of nets involved and biological information from animals caught, including the origin and magnitude of dolphin meat consumption or use of dolphin parts in rituals.

2) Based on the evaluation of the above in item 1, place mortality in a relative context to population size.

3) Based on the items 1 and 2, develop mitigation measures tailored to local socio-economic contexts and realities, recognizing that without such considerations mitigation measures might not be effective.

\section{Chemical pollution}

1) Increase the geographic extent of ecotoxicological investigations.

2) Increase the effort on determination of highly toxic emerging compounds (e.g. PBDEs, PFCs).

3) Perform studies on trophic transfer of pollutants in ecosystems used by Sotalia species, especially in critical areas from South and Southeast Brazil.

4) Conduct contaminant-specific biomarker assays of exposure and effects.

5) Perform pollutant level monitoring of Sotalia through remote biopsy sampling of skin and blubber.

\section{ACOUSTIC POLLUTION}

1) Investigate the potential effects of man-made noise (including seismic activities) on behavior, habitat use and sound emissions of Sotalia.

WATER DAMS AND GOLD MINING

1) Establish a baseline of information on at least two potentially important types of threat: water development projects and gold mining operations. Produce a document similar to the Register of Water Development Projects Affecting River Cetaceans in Asia (Smith et al., 2000). It should list all dams and other artificial barriers as well as gold mining sites in the river systems inhabited by one or both South American river dolphin species. Technical and geographic details and accurate maps showing the locations of water development and gold mining projects should be included. This initiative is viewed as an important first step in evaluating the magnitude of these threats and recommending appropriate mitigation and management.

\section{TOURISM}

1) In partnership with stakeholders (public and private sector, academia, etc.), develop measures to improve tourism management, such as codes of conduct, especially for dolphin watching activities within the limits of protected areas, including licensing and training of operators and personnel involved.

2) Develop management plans for protected areas of relevance to Sotalia along with monitoring of benefits generated.

3) Recommend Brazilian authorities to urgently elaborate, publish and implement the management plan for the APA Anhatomirim.

4) Further assess the potential impacts of boat traffic (speed of pleasure boats and jet skis) in both the marine and freshwater environments.

\section{HABITAT LOSS}

1) Monitor habitat use patterns by Sotalia populations and anthropogenic activities within protected areas.

2) Integrate Sotalia dolphin research and conservation into ecological studies and educational programs in existing protected areas.

3) Define areas of great relevance for the conservation of the species aiming the definition of new protected areas or other measures to reduce the impacts on important habitats for the species.

4) Enforce regulations where protected areas already exist.

\section{Acknowledgements}

The authors wish to thank Salvatore Siciliano and the organizing team of the workshop for their support and hospitality during the meeting. They are also very grateful to two anonymous reviewers, Michael Belanger, Marcos Santos, Carlos Olavarría and Daniel M. Palacios for kindly reviewing earlier versions of the manuscript and providing useful comments in order to improve it.

\section{References}

Aguilar, A. (1987) Using organochlorine pollutants to discriminate marine mammal populations: a review and critique of the methods. Marine Mammal Science 3(3): 242-262.

Alves, R.R.N. AND Rosas, I.L. (2008) Use of tucuxi dolphin Sotalia fluviatilis for medicinal and magic/religious purposes in North of Brazil. Human Ecology 36(3): 443-447. http://dx.doi.org/ $10.1007 /$ s10745-008-9174-5

Azevedo, A. F., Van Sluys, M., Dorneles, P. R., Lailson-Brito, J. Jr. Trends in Sotalia guianensis abundance in Guanabara Bay, Southeastern Brazil in XIII Reunión de Trabajo de Especialistas en Mamíferos Acuáticos de América del Sur, 2008, Montevideo.

Bandoli J.G., de Oliveira C.A.B. (1977) Toxoplasmose em Sotalia guianensis (Van Beneden, 1863), Cetacea, Delphinidae. Folha Medica 75:459-468

Barthem, R. AND Goulding, M. (1997) The Catfish connection. Ecology, migration and conservation of Amazonian predators. Columbia University Press. New York. 144p.

Beltrán, S. (1998) Captura accidental de Sotalia fluviatilis (Gervais, 
1853) na pescaria artesanal do Estuário Amazônico. M.Sc. Thesis. Universidade do Amazonas, Manaus, Brasil.

BEST, R.C. AND DA SILVA, V.M.F. (1989) Biology, status and conservation of Inia geoffrensis in the Amazon and Orinoco basins. Pages 23-34 in Perrin, W.F., Brownell Jr., R.L., Zhou, K. and Liu, J. (Eds) Biology and conservation of the river dolphins. IUCN Species Survival Commission Occasional Paper No. 3.

Borobia. M., Siciliano, S., Lodi. L., And Hoek, W. (1991) Distribution of the South American dolphin Sotalia fluviatilis. Canadian Journal of Zoology 69(4): 1025-1039. http:/ / dx.doi.org/ $10.1139 /$ z91-148

Caballero, S., Truilllo, F., Vianna, J.A., Barrios-Garrido, H., Montiel, M.G., Beltrán-Pedreros, S., Marmontel, M., Santos, M.C.O., Rossi-Santos, M., SAntos, F.R. And BAKER, C.S. (2007) Taxonomic status of the genus Sotalia: species level ranking for 'tucuxi' (Sotalia fluviatilis) and "costero" (Sotalia guianensis) dolphins. Marine Mammal Science 23(2): 358-386. http://dx.doi.org/10.1111/j.1748-7692.2007.00110.x

Caldwell D.K., Caldwell M.C., Woodard J.C., Ajello L., Kaplan W., AND MCLuRE H.M. (1975) Lobomycosis as a disease of the Atlantic bottle-nosed dolphin (Tursiops truncatus Montagu, 1821). American Journal of Tropical Medicine 24:105-114

CARR, T. AND BONDE, R.K. (2000) Tucuxi (Sotalia fluviatilis) occurs in Nicaragua, $800 \mathrm{~km}$ north of its previously known range. Marine Mammal Science 16(2): 447-452. http:/ / dx.doi.org/ 10.1111/j.1748-7692.2000.tb00936.x

CODESP (1992) Port of Santos, Brazil - 100 years (1892-1992). Companhia Docas do Estado de São Paulo (CODESP). 25 pp.

Covaci A., Van De Vijver I., De Coen W., Das K., Bouguegneau J.M., Blust R., AND Schepens P. (2002) Determination of organohalogenated contaminants in liver of harbour porpoises (Phocoena phocoena) stranded on the Belgian North Sea coast. Marine Pollution Bulletin 44: 1156.

Cremer M.J., Simões-Lopes, P.C., AND PIReS J.S.R (2009) Occupation pattern of a harbor inlet by the estuarine dolphin, Sotalia guianensis (P. J. Van Bénéden, 1864) (Cetacea, Delphinidae). Brazilian Archives of Biology and Technology 52(3): 765-774. http://dx.doi.org/10.1590/S1516-89132009000300029

CuLIK, B.M. (2004) Review of small cetaceans: Distribution, behaviour, migration and threats. Marine Mammal Action Plan, Regional Seas Reports and Studies 177: 343 pp.

Cunha, H.A., Da Silva, V.M. F., Lailson-Brito, J., Santos, M.C.O., Flores, P.A.C., Martin, A.R., Azevedo, A.F., Fragoso, A.B.L., Zanelatto, R.C. AND Sole-Cava, A.M. (2005) Riverine and marine ecotypes of Sotalia dolphins are different species. Marine Biology 148(2): 449-457. http:/ /dx.doi.org/10.1007/s00227-005-0078-2

DA Silva, V.M.F. AND Best, R.C. (1994) Tucuxi Sotalia fluviatilis (Gervais, 1853). Pages 43-69 in Ridgway, S.H. and Harrison, R. (Eds), Handbook of marine mammals, Volume 5 The first book of dolphins. Academic Press, London, UK.

DA Silva, V.M.F. AND Best, R.C. (1996) Sotalia fluviatilis. Mammalian Species 527: 1-7. http:/ / dx.doi.org/10.2307/3504117

da Silva, V.M.F., FetTuccia, D., Rodrigues, E.S., Edwards, H., Moreno, I.B., Moura, J.F., Wedekin, L.L., BAZZALO, M., Emin-Lima, N.R., CARMo, N.A.S., Siciliano, S. AND Utreras B., V. (2010) Report of the Working Group on Distribution, Habitat Characteristics and Preferences, and Group Size. Latin American Journal of Aquatic
Mammals 8(1-2): 31-38. http://dx.doi.org/10.5597/lajam00151

DiAs, C.P. (2007) Avaliação dos efeitos da poluição sonora na Baía da Babitonga, Santa Catarina, Brasil. Monografia. Universidade da Região de Joinville.

Di BENEDITTO, A.P.M. (2003) Interactions between gillnet fisheries and small cetaceans in northern Rio de Janiero, Brazil: 20012002. Latin American Journal of Aquatic Mammals 2(2): 79-86. http://dx.doi.org/10.5597/lajam00035

Di Beneditto, A.P.M., Ramos, R.M.A, AND Lima, N.R.W. (1998) Fishing activity in northern Rio de Janeiro State (Brazil) and its relation with small cetaceans. Brazilian Archives of Biology and Technology 41(3): 296-302.

Dorneles, P.R., LaILSON-Brito, J., SANtos, R.A., Costa, P.A.S., Malm, O., Azevedo, A.F., AND Torres, J.P.M. (2007). Cephalopods and cetaceans as indicators of offshore bioavailability of cadmium off Central South Brazil Bight. Environmental Pollution 148: 352-359.

Dorneles, P.R., Lailson-Brito, J., Fernandez, M., Vidal, L., Barbosa, L., Azevedo, A.F., Fragoso, A.B.L., Torres, J.P.M. AND MALM, O. (2008a) Evaluation of cetacean exposure to organotin compounds in Brazilian waters through hepatic total tin concentrations. Environmental Pollution 156(3): 1268-1276. http://dx.doi.org/10.1016/j.envpol.2008.03.007

Dorneles, P.R., Lailson-Brito, J., Eppe, G., Azevedo, A.F., Azevedo-Silva, C.E., Torres, J.P.M., Malm, O., Lepoint, G. AND DAs, K. (2008b) PCDD, PCDF and PCB determination in dolphins reveals a world hotspot for PCBs in Guanabara Bay, Brazil. Organohalogen Compounds 70: 1255-1258

Dorneles, P.R., Lailson-Brito, J., Azevedo, A.F., MeYer, J., Vidal, L.G., Fragoso, A.B., Torres, J.P., Malm, O., Blust, R. and Das, K. (2008c) High accumulation of Perfluorooctane Sulfonate (PFOS) in marine tucuxi dolphins (Sotalia guianensis) from the Brazilian coast. Environment, Science and Technology 42(14): 5368-5373. http://dx.doi.org/10.1021/es800702k

Dorneles, P.R., Lailson-Brito, J., Dirtu, A.C., Weiss, L., Azevedo, A.F., Torres, J.P.M., Malm, O., Neels, H., Blust, R., Das, K. AND CovacI, A. (2010) Anthropogenic and naturally-produced organobrominated compounds in marine mammals from Brazil. Environment International 36(1): 60-67. http://dx.doi.org/ 10.1016/j.envint.2009.10.001

Duinker, J.C., Hillebrand, M.T.J., Zeinstra, T. and Boon, J.P. (1989) Individual chlorinated biphenyls and pesticides in tissue of some cetaceans from the North Sea and the Atlantic Ocean: tissue distribution and biotransformation. Aquatic Mammals 15(3): 95-124.

EdwARDS, H. H. AND SCHNELL, G. D. (2001) Status and ecology of Sotalia fluviatilis in the Cayos Miskito Reserve, Nicaragua. Marine Mammal Science 17:445-472.

Flores, P.A.C., Bazzalo, M., Caballero, S., Santos, M.C.O., RossiSantos, M.R., Trujlllo, F., Bolaños-Jimenez, J., CREMER, M.J., MAYCollado, L.J., Silva, F.J.L., Montiel, M.G., Azevedo, A.F., Meirelles, A.C.O., Flach, L., Barrios, H., SimÕes-Lopes, P.C., Cunha, H.A. and Van Waerebeek, K. (2010) Proposed English common name for the Neotropical delphinid Sotalia guianensis (P.-J. Van Beneden, 1864). Latin American Journal of Aquatic Mammals 8(1-2): 179-181. http:/ /dx.doi.org/10.5597/lajam00167

Flores P.A.C. AND DA SIlva V.M.F. (2009) Tucuxi and Guiana Dolphin - Sotalia fluviatilis and S. guianensis. Pages 1188-1192 in PerRIN, W.F., WÜRsIG, B. AND ThewISSEn, J.G.M. (Eds) Encyclopedia of marine mammals, $2^{\text {nd }}$. Ed., Academic Press. 
Geise, L. AND Borobia, M. (1988) Sobre a occorrencia de cetaceos no litoral do Estado do Rio de Janiero, entre 1968 e 1984. Revista Brasiliera de Zoologia 4(4): 341-346. http:/ / dx.doi.org/10.1590/ S0101-81751987000400006

Guimarães, J.R.D., Roulet, M., Lucotte, M. and Mergler, D. (2000) Mercury methylation potentials along a lake-forest transect in the Tapajós river floodplain, Brazilian Amazon: seasonal and vertical variations. Science of the Total Environment 261(1): 91-98.

Henningsen, T. (1998) Zur Verbreitung, Habitatwahl und Verhaltensökologie der Delphine Inia geoffrensis und Sotalia fluviatilis im Oberlauf des Amazonas. Ph.D. Thesis. Zentrum für MarineTropenökologie, Bremen, Germany. 139 pp.

IBAMA. (2001) Mamíferos aquáticos do Brasil: Plano de ação. Versão II. 2nd ed. Instituto Brasileiro do Meio Ambiente e dos Recursos Naturais Renováveis. Brasília, Brasil.

IWC (1995) Report of the workshop. Report of the International Whaling Commission 45: 53-221.

Kajimara, N., Matsuoka, S., Inata, H., Tanabe, S., Rosas, F. C. W., Fillmann, G., and Readman, J.W. (2004) Contamination by persistent organochlorines in cetaceans incidentally caught along Brazilian coastal waters. Archives of Environmental Contamination and Toxicology 46:124-134.

Koeman, J.H., Peters, W.H.M., Smit, C.T., TJioe, P.S. AND DE GoeiJ, J.J.M. (1972) Persistent chemicals in marine mammals. TNO News 27: 570-578

Kunito, T., Nakamura, S., Ikemoto, T., Aana, Y., Kubota, R., Tanabe, S., Rosas, F. C. W. Fillmann, G., and Readman, J. W. (2004) Concentration and subcellular distribution of trace elements in liver of small cetaceans incidentally caught along the Brazilian coast. Marine Pollution Bulletin 49:574-587.

LAILSON-BRITO, J. (1994) Determinação das concentrações de metais-traço ( $\mathrm{Fe}, \mathrm{Cu}, \mathrm{Zn}, \mathrm{Mn}, \mathrm{Cd}$, Cr e Pb) em tecidos de cetáceos da costa do Brasil. B.Sc. Thesis, Universidade do Estado do Rio de Janeiro, Brazil.

LAILSON-BRITO, JR. L. (2000) Estudo ecotoxicológico de metais-traço (Fé, $\mathrm{Cu}, \mathrm{Cd}$ e Pb) em cetáceos da costa do Estado do Rio de Janeiro. Niterói - RJ. M.Sc. Thesis. Universidade Federal, Rural do Rio de Janeiro - Ciências Ambientais e Florestais. Brazil.

Lailson-Brito, J. (2007) Bioacumulação de mercúrio, selênio e compostos organoclorados (DDT, PCB e HCB) em cetáceos da costa Sudeste e Sul do Brasil. Ph.D. Thesis, Universidade Federal do Rio de Janeiro, RJ, Brazil.

Lailson-Brito, J., Azerado, M. A. A., SAldanha, M. F. C., Fernandez, M. A. AND HERMS, F. (2000) Estudo ecotoxicologico da concentracoes de cadmio em tecidos de golfinhos (Cetacea, Delephinidae) de habitos costeiros e oceanicos, de aguas do Estado do Rio de Janeiro. Pages 183-197 in E.L.G. Espindola et al. (Orgs.), Ecotoxicologia Perspectvas Para o Seculo XXI. Sao Carlos.

Lailson-Brito, J., Kehrig, H. A. and Malm, O. (2002) Mercúrio total nos tecidos do boto-cinza, Sotalia fluviatilis (cetacea, delphinidae), da Baía de Guanabara, Rio de Janeiro, Brasil. Pages: 291-300 in: Ricardo Prego; Armando Duarte; Alexandre V. Panteleitchouk; Teresa Rocha Santos. (Org.). Estudos sobre Contaminação Ambiental na Península Ibérica. Viseu: Piaget, 2002.

Lailson-Brito, J., Meire, R.O., Silva, C.E.A., Massene, E.P., Azerado, A., Torres, J.P. AND Malm, O. (2003) DDT and PCB in blubber of killer whale, Orcinus orca, and marine tucuxi dolphin, Sotalia fluviatilis, from Rio de Janeiro State, Brazil-Preliminary results. Organohalogen Compounds 52: 364-366.

Lailson-BRito, J., Dorneles, P.R., DA Silva, V.M.F., Martin, A.R., Bastos, W., Azevedo-Silva, C.E., Azevedo, A., Torres, J.P.M. AND Malm, O. (2008) Dolphins as indicators of micropollutant trophic flow in Amazon basin. Oecologia Brasiliensis 12(3): 527537. http:// dx.doi.org/10.4257/oeco.2008.1203.12

Lailson-Brito J., Dorneles P.R., Azevedo-Silva C.E., Azevedo A.F., Vidal L.G., Azevedo A., Fragoso A.B.L., Cunha H.A., Torres J.P.M. ANd Malm O. (2010) High organochlorine accumulation in blubber of Guiana dolphin, Sotalia guianensis, from Brazilian coast and its use to establish geographical differences among populations. Environmental Pollution 158(5): 1800-1808. http://dx.doi.org/10.1016/j.envpol.2009.11.002

LEATHERWOOD, S. (1996) Distributional ecology and conservation status of river dolphins (Inia geoffrensis and Sotalia fluviatilis) in portions of the Peruvian Amazon. Ph.D. Thesis Texas A\&M University.

Lodi, L. and CAPISTRAnO, L. (1990) Capturas acidentais de pequenos cetáceos no litoral norte do Estado do Rio de Janeiro. Biotemas 3(1): 47-65.

Loch, C., Marmontel, M., and Simões-Lopes, P.C. (2009) Conflicts with fisheries and intentional killing of freshwater dolphins (Cetacea: Odontoceti) in the Western Brazilian Amazon. Biodiversity and Conservation 18(14): 3979-3988. http:/ /dx.doi.org/10.1007/s10531-009-9693-4

Luederwaldt, H. (1919) Os manguesaes de Santos. Revista Museo Paulista 2: 309-408.

McGuire, T.L. (2002) Distribution and abundance of river dolphins in the Peruvian Amazon. Ph.D. Thesis, Wildlife and Fisheries Sciences, Texas A\&M University.

Monteiro Filho, E., Monteiro, L.R. And Reis, S.F. (2002) Skull shape and size divergence in dolphins of the genus Sotalia: a tridimensional morphometric analysis. Journal of Mammalogy 83(1): 125-134. http://dx.doi.org/10.1644/15451542(2002)083<0125:SSASDI>2.0.CO;2

Monteiro Neto, C., Alves-Júnior, T.T., Ávila, F.J.C., Campos, A.A., Costa, A.F., Silva, C.P.N. and Furtado Neto, M.A.A. (2000) Impact of fisheries on the tucuxi (Sotalia fluviatilis) and roughtoothed dolphin (Steno bredanensis) populations off Ceará state, northeastern Brazil. Aquatic Mammals 26(1):49-56.

Monteiro Neto, C., Itavo, R.V and Moraes, L.E.S. (2003) Concentrations of heavy metals in Sotalia fluviatilis (Cetacea: Delphinidae) off the coast of Ceará, northeast Brazil. Environmental Pollution 123(2): 319-324. http://dx.doi.org/ 10.1016/S0269-7491(02)00371-8

Monteiro Neto, C., Vila, F.J.C.A., Alves Jr., T.T., Araüjo D.S., Campos, A.A., Martins, A.M.A., Parente, C.L., Manuel, A., Furtado Neto, R. And LiEn, J. (2004) Behavioral responses of Sotalia fluviatilis (Cetacea, Delphinidae) to acoustic pingers, Fortaleza, Brazil. Marine Mammal Science 20(1): 145-151. http:/ / dx.doi.org/10.1111/j.1748-7692.2004.tb01145.x

Nery, M.F., Espécie, M.A. AND SimÃo S.M. (2008a) Site fidelity of Sotalia guianensis (Cetacea: Delphinidae) in Sepetiba Bay, Rio de Janeiro, Brazil. Revista Brasileira de Zoologia 25(2): 182-187.

NeRY, M.F., EspéCIE, M.A. AND SIMÃo S.M. (2008b) Marine tucuxi dolphin (Sotalia guianensis) injuries as a possible indicator of fisheries interaction in southeastern Brazil. Brazilian Journal of Oceanography 56(4): 313-316. http:/ / dx.doi.org/10.1590/S167987592008000400007 
Paniz-Mondolfi A.E., Reyes-Jaimes O., Dávila-Jones L. (2007) Lobomycosis in Venezuela. International Journal Dermatology 46:180-185

Pereira, M.G., Bazzalo, M. and Flores, P.A. (2007) Reações comportamentais na superficie de Sotalia guianensis (Cetacea: Delphinidae) durante encontros com embarcações na Baía Norte de Santa Catarina. Revista Brasileira de Zoociencias 9(2): 123-135.

Pinheiro, L. AND CREMER, M.J. (2004) Etnoecologia e captura acidental de golfinhos (Cetacea: Pontoporiidae e Delphinidae) na Baia da Babitonga, Santa Catarina. Meio Ambiente e Desenvolvimento 8: 69-76.

Reeves, R.R., Smith, B.D., CRespo, E.A. and Notarbartolo di Sciara, G. (Compilers) (2003) Dolphins, Whales, and Porpoises: 2002-2010. Conservation Action Plan for the World's Cetaceans. IUCN/SSC Cetacean Specialist Group, IUCN Gland, Switzerland and Cambridge, UK. Ix + 139 pp.

Rodríguez, J.P. AND F. RojAs-SuÁREZ (Eds.) (2008) Libro Rojo de la Fauna Venezolana. Tercera Edición. Provita y Shell Venezuela, S.A., Caracas, Venezuela. 364 pp.

Rodríguez-Mahecha, J., Alberico, M., Trujillo, F. AND Jorgenson, J. (Eds.) (2006) Libro Rojo de los Mamíferos de Colombia. Serie Libros Rojos de Especies Amenazadas de Colombia. Conservación Internacional Colombia, Ministerio de Ambiente, Vivienda y Desarrollo Territorial, Bogotá.

Rossi-Santos M.R., Wedekin, L.L., and Monteiro Filho, E.L.A. (2007) Residence and site fidelity of Sotalia guianensis in the Caravelas river estuary, eastern Brazil. Journal of the Marine Biological Association of the United Kingdom 87(1): 207-212. http:/ / dx.doi.org/10.1017/S0025315407055683

Santos, M.C.O., Acuña, L.B. And Rosso, S., (2001) Insights on site fidelity and calving intervals of the marine tucuxi dolphin (Sotalia fluviatilis) in south-eastern Brazil. Journal of the Marine Biological Association of the United Kingdom 81(6): 1049-1052. http:/ / dx.doi.org/10.1017/S0025315401005045

Santos, M.C.O., Cremer, M.J., Secchi, E.R., Flach, L., Filla, G., Hubner, A., AND Dussán-DuQue, S. (2010) Report of the Working Group on Population Abundance and Density Estimation. Latin American Journal of Aquatic Mammals 8(1-2): 39-45. http://dx.doi.org/10.5597/lajam00152

Seixas, T.G., Kehrig, H.A., Palermo, E.A., Di Beneditto, A.P.M., SOUZA, CMM, Malm, O. AND MoreIRA, I. (2009a) Essential (Se, $\mathrm{Cu})$ and non-essential $(\mathrm{Ag}, \mathrm{Hg}, \mathrm{Cd})$ elements: What are their relationships in liver of Sotalia guianensis (Cetacea, Delphinidae). Marine Pollution Bulletin 58(4): 629-634. http://dx.doi.org/ 10.1016/j.marpolbul.2008.12.005

Seixas, T.G., Kehrig, H.A., Di BeneditTo, A.P.M., Souza, C.M.M., Malm, O. And Moreira, I. (2009b) Trace elements in different species of cetacean from Rio de Janeiro coast. Journal of Brazilian Chemistry Society 20(2): 243-251. http:/ /dx.doi.org/10.1590/ S0103-50532009000200008

Siciliano, S. (1994) Review of small cetaceans and fishery interactions in coastal waters of Brazil. Report of the International Whaling Commission Special Issue 15: 241-250.

SYMmERs W.S. (1983) A possible case of Lobo's disease acquired in Europe from a bottle-nosed dolphin (Tursiops truncatus). Bulletin Society Pathology Exotic Filiales 76: 777-784

Smith, B.D. and Reeves, R.R. (Eds.) (2000) Report of the workshop on the effects of water development on river cetaceans, 26-28 February 1997, Rajendrapur, Bangladesh. Pages 15-22 in Reeves, R.R., Smith, B.D. and Kasuya T. (Eds) Biology and conservation of freshwater cetaceans in Asia. IUCN Species Survival Commission Occasional Paper No. 23.

Smith, B.D., Sinha, R.K., Zhou, K., Chaudhry, A.A., Renjun, L., Wang, D., Ahmed, B., Haque, A.K.M. and Sapkota, K. (2000) Register of water development projects affecting Asian river cetaceans. Pages 22-39 in Reeves, R.R., Smith, B.D. and Kasuya T. (Eds) Biology and Conservation of Freshwater Cetaceans in Asia. IUCN Species Survival Commission Occasional Paper No. 23.

Solé-Cava, A.M., Caballero, S., Bonvicino, C.R., Sholl, T.G.C., Moreno, I.B., AND Flores, P.A.C. (2010) Report of the Working Group on Taxonomy and Genetics. Latin American Journal of Aquatic Mammals 8(1-2): 25-29. http://dx.doi.org/10.5597/ lajam00150

TIRIRA, D. (2001) Libro rojo de mamíferos del Ecuador. EcoCiencia, Quito.

Torres, J.P., Lailson-Brito, J., Dorneles, P.R., Azevedo e Silva, C.E., Azerado, A., Meire, R.O., Vidal, L., Lozinski C., Azevedo, A.F., AND MALM, O. (2006) Organochlorines in blubber of marine tucuxi dolphin, Sotalia guianensis, from Rio de Janeiro coastal bays, Brazil. Organohalogen Compounds 68: 580-582.

TrujILlo, F. (1990). Aspectos ecológicos y etológicos de los delfines Inia geoffrensis (de Blainville, 1817) y Sotalia fluviatilis (Gervais, 1853) en la Amazonia colombiana. B.Sc. Thesis. Universidad Jorge Tadeo Lozano. 70 pp.

Utreras, V., Tirira, D. AND DenkIngER, D.J. (2000) Sotalia fluviatilis, delfín gris de río. Pages 80-81 in Tirira, D. (Ed), Libro Rojo de los Mamíferos del Ecuador, SIMBIOE, Quito, Ecuador.

Van Bressem, M-F., Van Waerebeek, K., Reyes, J.C., Félix, F., Echegaray, M., Siciliano, S., Di BeneditTo, A.P., Flach, L., Viddi, F., Avila, I.C., Herrera, J.C., Tobón, I.C., Bolaños-Jiménez, J., Moreno, I.B., Ott, P.H., Sanino, G.P., Castineira, E., Montes, D., Crespo, E., Flores, P.A.C., HAase, B., Mendonça De SOUZA, S.M.F., LAETA, M. AND Fragoso, A.B. (2007) A preliminary overview of skin and skeletal diseases and traumata in small cetaceans from South American waters. Latin American Journal of Aquatic Mammals 6(1): 7-42. http://dx.doi.org/10.5597/lajam00108

VAn BRessem, M-F., SANTos, M.C.O. AND Oshima, J.E.F., (2009) Skin diseases in Guiana dolphins (Sotalia guianensis) from the Paranaguá estuary, Brazil: a possible indicator of a compromised marine environment. Marine Environment Research 67(1): 63-68. http:/ / dx.doi.org/10.1016/j.marenvres.2008.11.002

VIDAL, L.G. (2010) O uso do boto-cinza (Sotalia guianensis) como sentinela da poluição ambiental por compostos organoclorados (DDT, PCB, HCH, HCB e Mirex) em baías costeiras do Estado do Rio de Janeiro. M.Sc. Thesis, Universidade do Estado do Rio de Janeiro, RJ, Brasil.

Vidal, O., VAn Waerebeek, K., AND Findley, L.T. (1994) Cetaceans and gillnet fisheries in Mexico, Central America and the wider Caribbean: a preliminary review. Report of the International Whaling Commission Special Issue 15: 221-233.

Wedekin, L.L., Ré, M.A., DauRA-Jorge, F.G. AND SimÕes-Lopes, P.C. (2005) O uso de um modelo conceitual para descrever o cenário de conservação do boto-cinza n Baia Norte, sul do Brasil. Nature Conservation 3(1): 59-67.

Yogui, G.T., Santos, M.C.O. and Montone, R. C. (2003) 
Chlorinated pesticides and polychlorinated biphenyls in marine tucuxi dolphins (Sotalia fluviatlis) from the Cananéia estuary, southeastern Brazil. Science of the Total Environment 312:67-78

Yogui, G.T.; Santos, M.C.O.; Bertozzi, C.P.; Montone, R.C. (2010) Levels of persistent organic pollutants and residual pattern of DDTs in small cetaceans from the coast of São Paulo, Brazil. Marine Pollution Bulletin 60: 1862-1867.

ZANelatto, R.C. (2001) Avaliação de regiões de manguezais como áreas de alimentação para o boto-cinza, Sotalia fluviatilis (Cetacea,
Delphinidae), no complexo estuarino da Baía de Paranaguá, Paraná. M.Sc. Thesis. Universidade Federal de Paraná, Paraná, Brasil.

Zapata-Ríos, G. AND UtRERAS, V. (2004) Notes on the distribution of tucuxi, Sotalia fluviatilis (Cetacea: Delphinidae), in Ecuadorian Amazonia. Latin American Journal of Aquatic Mammals 3(1): 8587. http://dx.doi.org/10.5597/lajam00054

ZÚÑIGA, E.L. (1999) Seasonal distribution of freshwater dolphins in Tipishca del Samiria, Peru. M.Sc. Thesis. Texas A\&M University. College Station, Texas, USA. 126 pp. 